\title{
MEDICINE
}

\section{THE USE OF LABORATORY DIAGNOSTIC METHODS FOR THE ETIOLOGICAL INTERPRETATION OF ACUTE INTESTINAL INFECTIONS DURING THE WINTER PERIOD}

\author{
Master degree biologist Matsas $\mathbf{O}$. Yu., \\ Doctor laboratory assistant Mychalchuk G. A., \\ Doctor laboratory assistant bacteriologist Tsaryova O.M., \\ Doctor laboratory assistant Mulkina O.I., \\ Doctor laboratory assistant Slobodyanyuk O.M.
}

Oleksandrivskaya Clinical Hospital in Kyiv, Ukraine.

DOI: https://doi.org/ 10.31435/rsglobal_ws/31012019/6297

\section{ARTICLE INFO}

Received: 24 November 2018

Accepted: 27 January 2019

Published: 31 January 2019

\section{KEYWORDS}

acute intestinal infection, bacteriological research, molecular biological studies, pathogenic and conditionally pathogenic bacteria,

viral RNA specific fragments.

\begin{abstract}
The study analyzed the epidemiological situation of acute intestinal infections in the winter. Surveyed 98 patients. Bacteriologically, pathogenic and conditionally pathogenic bacteria cultures were isolated in $33.7 \%$, conditionally pathogenic cultures prevailed: Staphylococcus aureus - $23.5 \%$, Enterococcus aerogenes - 20.5\%, Klebsiella pneumoniae - 20.5\%, Citrobacter freundii - $14.7 \%$, Salmonella enteritidis - $11.7 \%$, Proteus vulgaris - 5.8\%, and the heteropathogenic Escherichia coli $\mathrm{O} 142$ was detected in $2.9 \%$. Specific fragments of viral RNA in $37.6 \%$ were identified by the molecular-biological method, Rotavirus A dominated - 55.2\%, Norovirus 2 genotype was found in $39.4 \%$. More often, the infection was caused by only one pathogen. Etiological factor is not defined in $33.7 \%$.
\end{abstract}

Citation: Matsas O. Yu., Mychalchuk G. A., Tsaryova O. M., Mulkina O. I., Slobodyanyuk O. M. (2019) The Use of Laboratory Diagnostic Methods for the Etiological Interpretation of Acute Intestinal Infections During the Winter Period. World Science. 1(41), Vol.2. doi: 10.31435/rsglobal_ws/31012019/6297

Copyright: (C) 2019 Matsas O. Yu., $\quad$ Mychalchuk G. A., $\quad$ Tsaryova O. M., $\quad$ Mulkina O. I., Slobodyanyuk O. M. This is an open-access article distributed under the terms of the Creative Commons Attribution License (CC BY). The use, distribution or reproduction in other forums is permitted, provided the original author(s) or licensor are credited and that the original publication in this journal is cited, in accordance with accepted academic practice. No use, distribution or reproduction is permitted which does not comply with these terms.

Введення. Гострі кишкові інфекції досить широко розповсюджені і займають друге місце після гострих респіраторних захворювань. За оцінками ВООЗ, щорічно на гострі кишкові інфекції хворіють понад 500 мільйонів людей. В Україні також склалася несприятлива епідеміологічна ситуація щодо розповсюдженості ГКІ. Особливо гостро стоїть ця проблема в дитячому віці. Як свідчать дані ВООЗ, дизентерія та інші ГКІ щорічно стають причиною смерті більше ніж 5 мільйонів дітей. [1, с.5].

Етіологічний чинник ГКІ вдається розшифрувати у 56-80\% випадків. Це можуть бути бактерії, віруси, гриби або ж найпростіші. Патогенетично прийнято розрізняти інвазивні та секреторні діареї. Раніше серед ГКІ переважали інвазивні діареї, зумовлені переважно бактеріальними збудниками такими як:

- д дизентерійна паличка;

- сальмонела;

- ентероінвазивна кишкова паличка;

- умовно патогенні бактерії (стафілокок, клебсієла, протей). 
В основі таких діарей лежить запальний процес стінки кишечника 3 розвитком інтоксикаційного синдрому. Зараз на перший план у всьому світі серед ГКІ виходять секреторні діареї, збудниками яких $є$ :

коронавіруси);

- віруси (рота-, адено-, астро-, каліци-, реовіруси, віруси Норфолку, кишкові

- бактерії (холерний вібріон, ентеропатогенні та ентеротоксигенні ешерихії);

- найпростіші (криптоспоридії, мікроспоридії, балантидії, ізоспори. [4].

Згідно 3 результатами сучасних епідеміологічних досліджень, в різних країнах етіологічна структура кишкових інфекцій може суттєво відрізнятися.

Так, якщо в економічно розвинутих країнах на вірусну етіологію гострих інфекційних діарей припадає 75-80\%, на бактеріальну - 15-20\% всіх верифікованих випадків, то в державах, що розвиваються, домінують захворювання бактеріальної етіології. Крім того, у деяких контингентів існує підвищений ризик захворювання на ГКІ. [3].

Етіологічна структура діарейних інфекцій залежить не стільки від регіону, де проводили дослідження, скільки від методів та способів детекції збудників. Так, за даними дослідників із Росії та Білорусі, у 12-33\% випадків ГКІ спричинені бактеріями (найчастіше умовнопатогенними мікроорганізмами), у 35,3-71,7\% - вірусами; етіологія 17,1-28\% випадків невідома. Віруси є домінуючими етіологічними чинниками як в період сезонного підйому захворюваності на ГКІ (65-76\% випадків), так і за результатами аналізу спорадичних випадків $(62,6 \%)$, причому у 47,9\% випадків це була моноінфекція, у 7,5-14,7\% - мікст-інфекція. У дослідженнях, проведених у Таджикистані, у зразках нативного матеріалу визначали бактеріальні патогени, ротавіруси (РВ), аденовіруси (АдВ) і астровіруси (АсВ). У 27,0\% випадків ГКІ мають бактеріальне, у 52,0\% - вірусне походження. В Україні етіологічне підтвердження має переважно РВ-гастроентерит. Тобто, незважаючи на результати досліджень, які підтверджують провідну роль вірусів в етіології кишкових інфекцій, у сучасних умовах їх значущість повсюдно недооцінена, має місце суттєва гіподіагностика. [2].

Серед гострих кишкових інфекцій (ГКІ) значна питома вага належить ентеритам, колітам, гастроентеритам та харчовим токсикоінфекціям, які спричинені невстановленими збудниками. Захворюваність на зазначену групу інфекцій в Україні зросла за досліджуваний період на 42,34\%. [6, с.52].

Для гострих кишкових інфекцій характерна літньо-осіння сезонність. В той же час на сучасному етапі дослідники встановили зміни сезонності ГКІ - 3 літньо-осіннього на зимововесняний період року. [5]

Враховуючи механізм передачі захворювання, діагноз встановлюють за епідеміологічним анамнезом, симптомами та клінічними проявами захворювання, а підтверджують різними лабораторними методами діагностики.

Мета дослідження - встановити епідеміологічні особливості гострих кишкових інфекцій з вираженим синдромом гастроентерита в зимовий час.

Матеріали та методи. Дослідження біоматеріалу були проведені в зимовий час -3 листопада по лютий. Зразки фекалій від 98 людей, які захворіли, доставили в лабораторію Олександрівської клінічної лікарні міста Києва наступного дня після госпіталізації 3 вираженими симптомами гастроентерита. Для виявлення бактерій застосували класичний бактеріологічний метод ідентифікації колоній з клінічно значимим епідеміологічним порогом. Дослідження на наявність вірусів проводились методом полімеразної ланцюгової реакції (ПЛР) 3 використанням набору реагентів «АмплиСенс Rotavirus A / Norovirus 2 генотип / Astrovirus FL» в одному зразку біоматериалу 3 гібридизаційно-флуоресцентною детекцією в режимі "реального часу".

Результати. В проведених дослідженнях був встановлений етіологічний агент гострої кишкової інфекції в 66,3\% (n=65) випадків. Бактеріологічним методом були виділені культури патогенних та умовно- патогенних бактерій в $33,7 \%(\mathrm{n}=34)$ випадків 3 клінічно значимим епідеміологічним порогом. Серед бактеріальних збудників гострих кишкових інфекцій переважали умовно-патогенні мікроорганізми: Staphylococcus aureus - 23,5\% (n=8), Enterococcus aerogenes - 20,5\% ( $n=7)$, Klebsiella pneumoniae $-20,5 \%(n=7)$, Citrobacter freundii $14,7(\mathrm{n}=5)$, Salmonella enteritidis $-11,7 \%(\mathrm{n}=4)$, Proteus vulgaris $-5,8 \%(\mathrm{n}=2)$, етеропатогенна Escherichia coli $\mathrm{O}_{142}$ була виявлена у 2,9\% (n=1). Практично у всіх епізодах це була 
моноінфекція. У трьох пацієнтів виявлена поєднана бактеріальна інфекція 3 двох збудників в пробі - Staphylococcus aureus и Klebsiella pneumoniae.

Молекулярно-біологічним методом було ідентифіковано специфічні фрагменти вірусних РНК у 37,6\% (n=38). Серед вірусних збудників гострих кишкових інфекцій домінував Rotavirus A - 55,2\% ( $\mathrm{n}=21)$; Norovirus 2 генотип виявлено у 39,4\% (n=15); Astrovirus виявлено у $5,2 \%(\mathrm{n}=2)$ пацієнтів. Як і у випадках 3 бактеріальними, вірусні інфекції визначались як моноінфекції.

Бактеріально-вірусна інфекція виявлена у 7,1\% (n=7). Етіологічний фактор не визначено $\mathrm{y} 33,7 \%(\mathrm{n}=33)$.

Підсумок. Гострі кишкові інфекції в зимовий період були обумовлені бактеріальними та вірусними агентами. Серед бактерій переважали умовно-патогенні мікроорганізми 3 клінічно значимим епідеміологічним порогом, а серед вірусів домінували Rotavirus и Norovirus. Частіше інфікування було обумовлене тільки одним збудником. Етіологічний фактор не визначено у 33,7\%.

\section{ЛІТЕРАТУРА}

1. Гостри кишкові інфекції у дітей (сучасні погляди на етиологію, патогенез, діагностику та лікування): нав. посб. МОЗ Украіни, ЗДМУ, каф. госп. пед. та дит. інфек. хв. - затв. 2013.05.23. прот № 5 - Запоріжжя 2014. - С.133.

2. Доан С.І. Гострі кишкові інфекції вірусної етіології: епідеміологічні аспекти [Електронний ресурс]/ С. Доан, Н. Малиш. // Український медичний Часопис 2015. - Т. 3, № 107 - V/VI https://www.umj.com.ua/article/87141/gostri-kishkovi-infekcii-virusnoi-etiologii-epidemiologichni-aspekti

3. Малый В.П. Общая характеристика острых кишечных инфекций [Електронний ресурс] / Малый В.П. // Клінічна імунологія Алергологія Інфектологія 2010. - Т. 7, №36 - https://kiai.com.ua/ru-issuearticle-504/Obshchaya-harakteristika-ostryh-kishechnyh-infekciy

4. Незгода I.I. Гострі кишкові інфекції актуальна проблема сьогодні [Електронний ресурс] / I. Незгода, О. Боднарюк // Дитячий Лікар 2012. - Т 8 № 21 - https://d-l.com.ua/ua-issue-article-212

5. Печеник А. С. Региональные особенности эпидемиологического процесса острых кишечных инфекций [Електронний ресурс] / Печеник А. С. // Медицинский альманах. 2011. - Т. 5, №18 https://cyberleninka.ru/article/v/regionalnye-osobennosti-epidemicheskogo-protsessa-ostryh-kishechnyh-infektsiy

6. Харитонюк Р. О. Медико-соціальне обгрунтування концепції оптимізації медичної допомоги інфекційним хворим на регіональному рівні: автореф. дис. ... канд. мед. наук: 14.02.03 / Р. О. Харитонюк; Нац. мед. акад. післядиплом. освіти ім. П. Л. Шупика. - К.: [б. и.], 2015. - Бібліогр.: С. 49 -64. 